\title{
A Review of the Global Emissions, Transport and REC E Effects of Heavy Metals in the Environment \\ Ju? \\ Osi,
}

June 1993

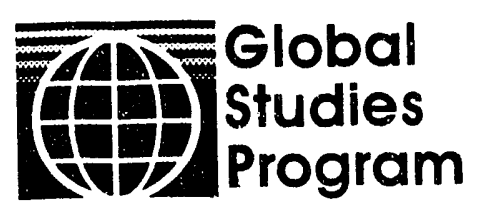

Pacific Northwest Laboratory 


\section{DISCLAIMER}

This report was prepared as an account of work sponsored by an agency of the United States Government. Neither the United States Government nor any agency thereof, nor Battelle Memorial Institute, nor any of their employees, makes any warranty, expressed or implied, or assumes any legal liability or responsibility for the accuracy, completeness, or usefulness of any information, apparatus, product, or process disclosed, or represents that its use would not infringe privately owned rights. Reference herein to any specific commercial product, process, or service by trade name, trademark, manufacturer, or otherwise does nut necessarily constitute or imply its endorsement, recommendation, or favoring by the United States Government or any agency thereof, or Battelle Memorial Institute. The views and opinions of authors expressed herein do not necessarily state or reflect those of the United States Government or any agency thereof.

PACIFIC NORTHWEST LABORATORY

operated by

BATTELLE MEMORIAL INSTITUTE

for the

UNITED STATES DEPARTMENT OF ENERGY

under Contract DE-AC06-76RLO 1830 


\section{A Review of the Global Emissions, Transport, and Effects of Heavy Metais in the Environment}

J. R. Friedman

Contributing authors:

W. B. Ashton

R. D. Rapoport

June 1993

Prepared for the U.S. Department of Energy under Contract DE-AC06-76RLO 1830

Pacific Northwest Laboratory

Richland, Washington 99352

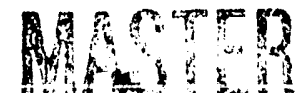




\section{Executive Summary}

The purpose of this report is to describe the current state of knowledge regarding the sources and quantities of heavy metal emissions, their transport and fate, their potential health and environmental effects, and strategies to control them. The approach is to review the literature on this topic and to consult with experts in the field. Ongoing research activities and research needs are discussed.

\section{Sources and Quantities of Heavy Metals Emissions}

Estimates of global anthropogenic and natural emissions indicate that anthropogenic emissions are responsible for most of the heavy metals released into the atmosphere and that industrial activities have had a significant impact on the global cycling of trace metals. The largest anthropogenic sources of trace metals are coal combustion and the nonferrous metal industry.

\section{Environmental Transport and Behavior}

Atmospheric deposition is an important pathway by which trace metals enter the environment. Atmospheric deposition varies according to the solubility of the element and the length of time it resides in the atmosphere. Meteorological evidence indicates that trace elements with long residence times (e.g., arsenic, cadmium, lead, and mercury) are found in high concentrations in regions far from the point of their initial release into the atmosphere. Evidence suggests that deposition is influenced by other chemicals in the atmosphere, such as ozone and sulfur dioxide.

Trace metals also enter the environment through leaching. Leaching occurs as metals are absorbed from sludge, runoff from coal piles, and discharges of ash pond water and other waste water. Leaching, which is dependent on the amount of water present and the solubility of the element, can contaminate surface water, groundwater, and soils.

\section{Environmental and Health Effects of Heavy Metals}

Health studies of air toxics have not traditionally focused on the risks to humans and animals through contamination of the food chain. The effects on humans are influenced by the impact of heavy metals on animals and ecosystems. Concentrations of some trace metals in fish and mammals exceed the health standards for humans. The effects of long-term human exposure to trace elements have not been fully explored.

\section{Control Strategies}

Existing emissions-control technologies such as electrostatic precipitators, baghouses, and scrubbers are designed to remove other particulates from the flue gas of coal-fired power plants and are only partially effective at removing heavy metals. Emerging technologies such as flue gas desulfurization, lignite coke, and fluidized bed combustion could further reduce emissions. 


\section{Ongoing Activities}

Several federal agencies are conducting research to understand the process and impact of heavy metal releases into the environment. The U.S. Department of Energy (DOE) is focusing on determining the contents of emissions from utility stacks. The U.S. Environmental Protection Agency (EPA) is carrying out three studies on air toxics: the first will focus on the health effects of direct exposure to emissions from utility plants, the second will focus on the transport and effects of mercury, and the third will focus on atmospheric deposition to the Great Lakes and coastal waters.

The Electric Power Research Institute (EPRI) also is conducting several studies regarding the transport and effects of emissions into the environment. The PICES (power plant integrated systems: chemical emissions study) project seeks to assess the source and fate of chemicals emitted by individual plants. A second project involves an effort to model human health risk from heavy metal emissions. Finally, EPRI is conducting a study on mercury in temperate lakes.

\section{Where Future Research Is Needed}

Current dara on the quantity of emissions, the environmental behavior, and the health and ecological effects of trace metals are inadequate. More study is needed to determine the relative strength of specific natural and anthropogenic sources. An inventory of these sources and the amounts they emit needs to be compiled. Research on the interaction of heavy metals with other chemicals in the atmosphere and in terrestrial systems needs to be conducted to understand the divergent effects metals can have on the environment. Control strategies, including a mix of hardware and policy options, need to be developed to reduce the risks posed by heavy metals.

\section{Conclusions}

Heavy metal emissions appear to be increasing, and anthropogenic sources appear to be the main contributor to this increase. The EPA may regulate utility emissions in the future. Outside of the United States, heavy metal pollution is expected to increase in developing countries, as the demand for goods and services increases. Research into heavy metals emissions needs to be conducted on a global scale using a holistic approach and focusing on the particulars of individual regions. 


\section{Contents}

Executive Summary $\ldots \ldots \ldots \ldots \ldots \ldots \ldots \ldots \ldots \ldots \ldots \ldots \ldots \ldots$

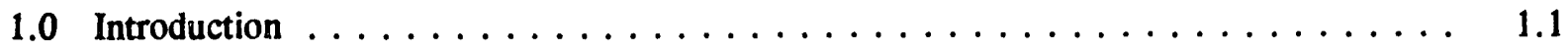

2.0 Sources and Quantities of Heavy Metal Emissions $\ldots \ldots \ldots \ldots \ldots \ldots$

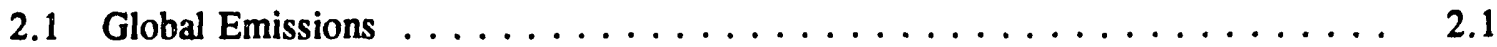

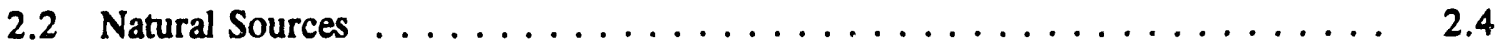

2.3 Anthropogenic Sources $\ldots \ldots \ldots \ldots \ldots \ldots \ldots \ldots \ldots \ldots \ldots \ldots \ldots$

2.3.1 Coal Combustion $\ldots \ldots \ldots \ldots \ldots \ldots \ldots \ldots \ldots \ldots \ldots \ldots \ldots$

2.3.2 Utility Emissions in the United States . . . . . . . . . . . . 2.8

2.3.3 Utility Emissions in Europe $\ldots \ldots \ldots \ldots \ldots \ldots \ldots \ldots \ldots$

2.3 .4 Oil Combustion $\ldots \ldots \ldots \ldots \ldots \ldots \ldots \ldots \ldots \ldots$

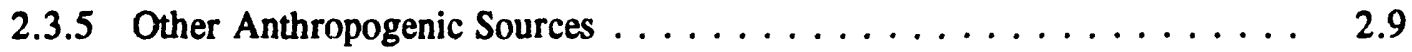

3.0 Environmental Transport and Behavior $\ldots \ldots \ldots \ldots \ldots \ldots \ldots \ldots \ldots \ldots$

3.1 Air Transport $\ldots \ldots \ldots \ldots \ldots \ldots \ldots \ldots \ldots \ldots \ldots \ldots \ldots \ldots \ldots$

3.2 Leaching and Other Transport Pathways $\ldots \ldots \ldots \ldots \ldots \ldots \ldots \ldots$

3.3 Relationship with Acid Rain $\ldots \ldots \ldots \ldots \ldots \ldots \ldots \ldots \ldots \ldots \ldots \ldots$

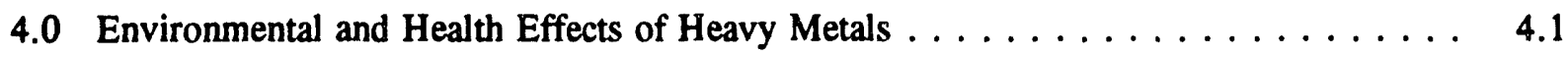

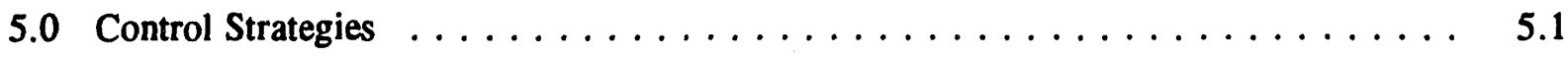

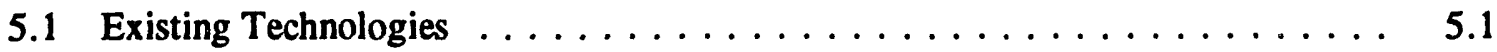

5.2 Developing Technologies $\ldots \ldots \ldots \ldots \ldots \ldots \ldots \ldots \ldots \ldots \ldots \ldots \ldots$

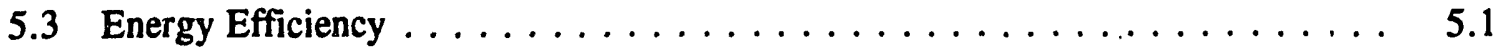

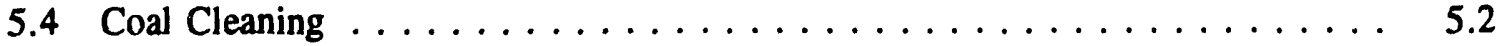

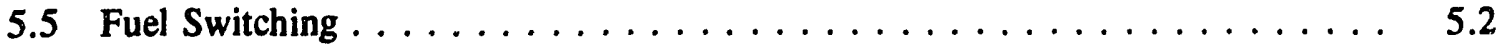




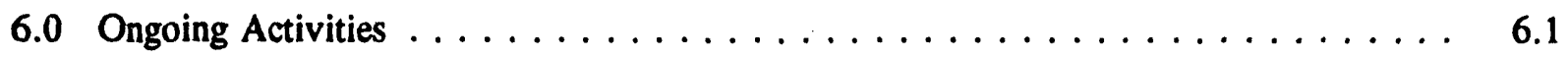

6.1 EPA Activities $\ldots \ldots \ldots \ldots \ldots \ldots \ldots \ldots \ldots \ldots \ldots \ldots \ldots \ldots$

6.1 .1 Utility Study $\ldots \ldots \ldots \ldots \ldots \ldots \ldots \ldots \ldots \ldots \ldots \ldots$

6.1 .2 Mercury Study $\ldots \ldots \ldots \ldots \ldots \ldots \ldots \ldots \ldots \ldots \ldots$

6.1.3 Great Waters Study . . . . . . . . . . . . . . . 6.1

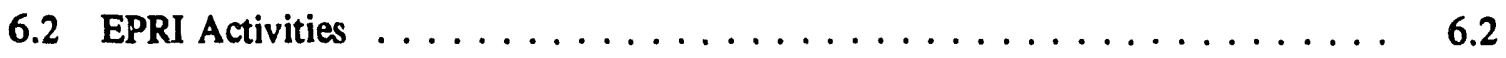

6.2.1 PICES Project $\ldots \ldots \ldots \ldots \ldots \ldots \ldots \ldots \ldots \ldots \ldots \ldots$

6.2.2 Human Health Risk Models . . . . . . . . . . . . . . . 6.2

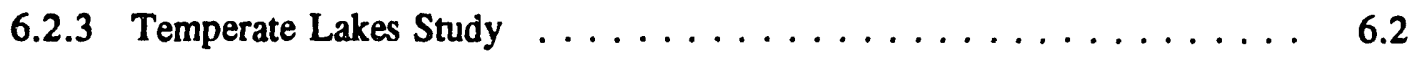

7.0 Areas Where Future Research Is Needed $\ldots \ldots \ldots \ldots \ldots \ldots \ldots$

7.1 Sources of Emissions $\ldots \ldots \ldots \ldots \ldots \ldots \ldots \ldots \ldots \ldots \ldots$

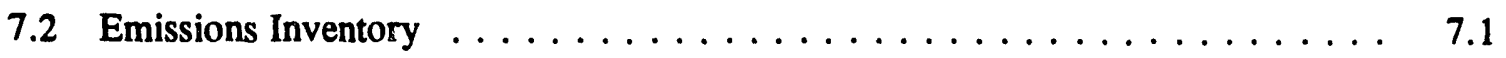

7.3 Behavior and Transport $\ldots \ldots \ldots \ldots \ldots \ldots \ldots \ldots \ldots \ldots \ldots$

7.4 Impacts of Trace Metal Emissions $\ldots \ldots \ldots \ldots \ldots \ldots \ldots \ldots \ldots \ldots \ldots$

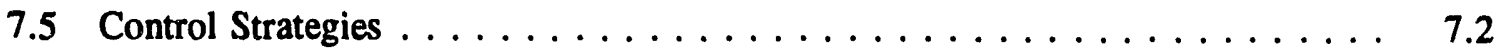

8.0 References $\ldots \ldots \ldots \ldots \ldots \ldots \ldots \ldots \ldots \ldots \ldots \ldots \ldots \ldots \ldots \ldots \ldots$

9.0 Bibliography $\ldots \ldots \ldots \ldots \ldots \ldots \ldots \ldots \ldots \ldots \ldots \ldots \ldots \ldots \ldots$ 


\section{Tables}

2.1 Natural Versus Anthropogenic Emissions of Trace Metals into the Atmosphere

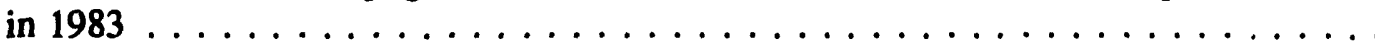

2.2 Global Anthropogenic and Natural Emissions for Select Metals $\ldots \ldots \ldots \ldots$

2.3 Sources of Natural Emissions of Heavy Metals $\ldots \ldots \ldots \ldots \ldots \ldots \ldots$

2.4 Sources of Anthropogenic Emissions of Heavy Metals $\ldots \ldots \ldots \ldots \ldots$

2.5 Estimated Recoverable Reserves of Coal Worldwide $\ldots \ldots \ldots \ldots \ldots$

2.6 Trace Metal Concentrations in Raw Coal $\ldots \ldots \ldots \ldots \ldots$

2.7 Utility Emissions of Selected Trace Metals in the United States $\ldots \ldots \ldots$. . . . . . 2.8

2.8 Utility Emissions of Selected Trace Metals in Europe in $1982 \ldots \ldots \ldots \ldots$

5.1 Efficiency of Control Technologies at Removing Mercury $\ldots \ldots \ldots \ldots \ldots$ 


\subsection{Introduction}

Fossil fuel combustion, metal production and manufacturing, incineration, and other industrial processes release heavy metals (trace metals or trace elements) into the atmosphere. These releases have increased the concentrations of heavy metals in ecosystems and threaten the environment and human health. Scientists have documented the danger from lead exposure, e.g., central nervous system, developmental and hematological damage; however, they do not yet completely understand the full consequences of increased human and ecological exposure to other trace metals. Some trace metals, such as mercury, are known to be especially dangerous in aquatic ecosystems where they tend to bioaccumulate in the food chain.

Heavy metal pollution could become a major global environmental problem. Heavy metals are often deposited in areas far from the source of emission. Because they are subject to long-range atmospheric transport, heavy metals emitted in one country could have negative repercussions on ecosystems in other countries, in areas far from industry. This is problematic because once released into the biosphere, these metals cannot be recovered using current technology (Nriagu 1990, p. 8). More research is needed to assess the effects of long-range transport and deposition of heavy metals on humans, animals, and the environment.

To reduce the emissions of heavy metals into the atmosphere, the sources and the amount must be identified. An understanding of the relative impact of the natural global cycles of these elements is needed to determine the significance of anthropogenic emissions. Studies on the global cycling of trace metals in the atmosphere provide rough estimates of emissions, revealing that manmade sources of some heavy metals are greater than the natural sources of these elements (Nriagu 1989b, p. 7). Currently, most of the anthropogenic emissions of trace metals are released from developed countries. As developing countries industrialize, howevei, they too can be expected to increase their contribution to global emissions. Since developing countries do not employ rigorous pollution control policies, heavy metal emissions may become a serious problem in the future.

While there has been significant research on the local effects of heavy metal emissions to the air, not much work has been done on the global environmental effects of the emissions of trace metals. Pacific Northwest Laboratory $(\mathrm{PNL})^{(\mathrm{a})}$ has gathered available information on this topic in an effort to assess the current state of knowledge and to identify areas for further research. The heavy metals considered in this paper are arsenic (As), cadmium (Cd), chromium $(\mathrm{Cr})$, copper $(\mathrm{Cu})$, mercury $(\mathrm{Hg})$, manganese $(\mathrm{Mn})$, nickel $(\mathrm{Ni})$, lead $(\mathrm{Pb})$, selenium $(\mathrm{Se})$, and zinc $(\mathrm{Zn})$.

The remainder of this report is organized as follows: sources and quantities of heavy metal emissions (Section 2.0), environmental transport and behavior (Section 3.0), environmental and health effects of heavy metals (Section 4.0), control strategies (Section 5.0), ongoing activities (Section 6.0), and areas where future research is needed (Section 7.0).

(a) Pacific Northwest Laboratory is operated for the U.S. Department of Energy by Battelle Memorial Institute under Contract DE-AC06-76RLO 1830. 


\subsection{Sources and Quantities of Heavy Metal Emissions}

Heavy metals are released from natural and anthropogenic sources. Natural emissions are released from point sources such as volcanoes, as well as from diffuse sources such as oceans. Anthropogenic emissions are usually released from point sources such as power plants and metal production facilities.

The effect of anthropogenic emissions on the environment depends on their relative significance compared with natural sources. Since anthropogenic fluxes have been studied more closely than natural sources (Mosher and Duce 1987 , p. 13289), quantifying the relative significance of each is difficult.

Natural emissions may be affected by anthropogenic sources (Lindqvist and Rodhe 1985, p. 148; Mosher and Duce 1987, p. 31292). Past anthropogenic emissions are probably cycling through the air, water, and soil and are increasing what we would consider to be present-day natural emissions. Thus, it is misleading to refer to present-day fluxes as natural even though they result from natural biological processes. Terms such as "preindustrial," "present," and "present background" are more descriptive. Since most authors do not make these distinctions, some emissions that are categorized as present-day natural emissions may be of anthropogenic origin.

\subsection{Global Emissions}

Very few estimates of global anthropogenic and natural emissions have been compiled. The most recent and comprehensive assessment of anthropogenic sources was compiled by Nriagu and Pacyna (1988) for the year 1983, and the most extensive appraisal of natural sources was calculated by Nriagu (1989a) for 1983 . These results are presented in Table 2.1 .

A comparison of these assessments reveals that emissions from anthropogenic sources exceed the flux for natural sources for most metals and that industrial activities have had a significant impact on the global cycling of trace metals. The anthropogenic emissions were calculated by applying emission factors to statistics on worldwide production and consumption of industrial goods. The emission factors were presented as ranges, taking into account the uncertainty in the concentration of trace metals in raw materials, the production technology used, and the control technologies employed (Nriagu and Pacyna 1988, p. 135). The natural emissions were also calculated from emission factors and published estimates of the mass fluxes from individual sources. There is great uncertainty in these data as well, which is reflected in the ranges given.

These results have been published in several sources (Pacyna 1989; Nriagu 1990). Based on these results, members of a workshop sponsored by the Center for Clean Air Policy concluded that most global atmospheric cycling of certain trace metal pollution is caused by industrial activity (Neme 1991, p. 112). Elias of the EPA stated that Nriagu and Pacyna's 1988 assessment reduced uncertainty by a factor of 2 or more for each metal and refined the emission factors for each source category (Elias 1989, p. 48).

Reported emissions for mercury are in agreement with the Nriagu and Pacyna estimates. Lindberg cites estimates of global anthropogenic emissions of mercury that are between 2000 and 3000 metric tons a year (Lindberg 1987, p. 90). Natural emissions are 
Table 2.1. Natural Versus Anthropogenic Emissions of Trace Metals into the Atmosphere in 1983 (thousand tons per year)

\begin{tabular}{|c|c|c|c|c|}
\hline $\begin{array}{l}\text { Trace } \\
\text { Metal } \\
\end{array}$ & $\begin{array}{l}\text { Anthropogenic } \\
\text { Emissions }{ }^{(\mathrm{a})} \\
\end{array}$ & $\begin{array}{c}\text { Natural } \\
\text { Emissions }^{(a)} \\
\end{array}$ & $\begin{array}{c}\text { Total } \\
\text { Emissions }^{(\mathrm{a})} \\
\end{array}$ & $\begin{array}{c}\text { Natural/Total } \\
\text { Emissions }\end{array}$ \\
\hline As & $19(12-26)$ & $12(0.86-23)$ & $31(12.86-49)$ & 0.39 \\
\hline $\mathrm{Cd}$ & $7.6(3.1-12)$ & $1.3(0.15-2.6)$ & $8.9(3.25-14.6)$ & 0.15 \\
\hline $\mathrm{Cr}$ & $30(7.3-54)$ & $44(4.5-83)$ & $74(11.8-137)$ & 0.59 \\
\hline $\mathrm{Cu}$ & $35(20-51)$ & $28(2.3-54)$ & $63(22.3-105)$ & 0.44 \\
\hline $\mathbf{H g}$ & $3.6(0.91-6.2)$ & $2.5(0.10-4.9)$ & $6.1(1.01-11.1)$ & 0.41 \\
\hline Mn & $38(11-66)$ & $317(52-582)$ & $355(63-648)$ & 0.89 \\
\hline $\mathrm{Ni}$ & $56(24-87)$ & $30(3.0-57)$ & $86(27-144)$ & 0.35 \\
\hline $\mathrm{Pb}$ & $332(289-376)$ & $12(0.97-23)$ & 344 (290-399) & 0.04 \\
\hline $\mathrm{Se}$ & $6.3(3.0-9.7)$ & $9.3(0.66-18)$ & $15.6(3.66-27.7)$ & 0.58 \\
\hline $\mathrm{Zn}$ & $132(70-194)$ & $45(4.0-86)$ & $177(74-280)$ & 0.34 \\
\hline
\end{tabular}

(a) These are median values with the ranges of estimated emissions given in parentheses.

Source: Nriagu 1989a, p. 49

estimated to be of the same order of magnitude. Lindqvist and Rodhe cite a comparable figure of 2400 tons of mercury emitted annually from anthropogenic sources (1985, p. 148).

Selenium estimates from other authors are also similar to those of Nriagu and Pacyna. The estimate for selenium reported by Ross (1985, p. 81-82), 6700 to 8000 tons for the year 1973, was within the range given by Nriagu and Pacyna. Mosher and Duce (1987) report anthropogenic selenium emissions to be 6000 tons and natural emissions to be between 6000 and 13,000 tons annually. Again, these numbers fall within Nriagu and Pacyna's range.

However, there are discrepancies between these figures and those reported by other authors. Chilvers and Peterson's estimate of 28,000 tons of anthropogenic arsenic emissions per year (1987) is higher than Nriagu and Pacyna's estimate, and their estimate for natural emissions (45.5 thousand tons per year) is almost 4 times as high. They estimate that volcanoes and low-temperature volatilization contribute more than 40,000 tons of arsenic. Based on these data, Chilvers and Peterson conclude that anthropogenic emissions do not have a great influence on average global concentrations. Chilvers and Peterson cite two other studies: Walsh et al. (1979) and Mackenzie and Wollast (1977). Data from Walsh et al. are comparable to the Nriagu and Pacyna data for arsenic, but Walsh et al. attribute almost all of the natural emissions to volcanoes. Mackenzie and Wollast estimate emissions to be much higher than any of the other estimates (82.9 thousand tons from anthropogenic sources, and 213.57 thousand tons from natural sources). Mackenzie and Wollast also attribute much of the arsenic emissions to the volatilization from oceans and from production of nonferrous metal.

Lantzy and Mackenzie have compiled the only other comprehensive assessment of natural and 
anthropogenic sources of trace metals (1979, p. 511-525). As Table 2.2 indicates, their estimates of anthropogenic emissions are much greater than those of Nriagu and Pacyna. Nriagu and Pacyna argue that Lantzy and Mackenzie did not always consider differences in industrial processes and pollution-control devices. For example, Lantzy and Mackenzie assume that $90 \%$ of the metals found in coal and oil are released into the atmosphere. Lantzy and Mackenzie also do not account for particulates settling near the source. The table also reveals that Lantzy and Mackenzie's estimates for natural sources are slightly lower, but of the same order of magnitude as those of Nriagu.

Emissions estimates are only one tool for evaluating the impact of anthropogenic sources on the cycling of trace metals in the environment. Comparing metal concentrations in the atmosphere to concentrations in the earth's crust can to lead to a better understanding of anthropogenic influences, as can the study of glaciers, peat bogs, and sediments to determined the historical trends of metal concentrations through atmospheric deposition. Based on actual measurements using historical trends, Galloway et al. (1982) found that "at least in the eastern United States, the rates of atmospheric deposition of cadmium, copper, lead, and zinc are strongly influenced, if not controlled, by anthropogenic processes."

On the other hand, Jaworowski et al. (1981), who used data from glaciers in Norway, Alaska and South America, did not find evidence of changes in the rate of metal deposition during the past 30 years compared with the pre-industrial period. Anthropogenic sources were considered to contribute only a small fraction to the global cycles of lead, cadmium, and mercury. Jaworowski attributes increases in the concenirations of heavy metals in remote regions to natural processes that enrich metals in airborne dust. $\mathrm{He}$ argues that

Table 2.2. Global Anthropogenic and Natural Emissions for Select Metals (thousand tons per year)

\begin{tabular}{|c|c|c|c|}
\hline $\begin{array}{l}\text { Trace } \\
\text { Metal } \\
\end{array}$ & $\begin{array}{l}\text { Anthropogenic } \\
\text { Emissions }\end{array}$ & $\begin{array}{c}\text { Natural } \\
\text { Emissions }\end{array}$ & $\begin{array}{c}\text { Total } \\
\text { Emissions }\end{array}$ \\
\hline As & 78.00 & 2.80 & 80.80 \\
\hline $\mathrm{Cd}$ & 5.50 & 0.29 & 5.79 \\
\hline $\mathrm{Cr}$ & 94.00 & 58.40 & 152.40 \\
\hline $\mathrm{Cu}$ & 263.00 & 19.00 & 282.00 \\
\hline $\mathrm{Hg}$ & 11.00 & 0.04 & 11.04 \\
\hline $\mathrm{Mn}$ & 316.00 & 605.00 & 921.00 \\
\hline $\mathrm{Ni}$ & 98.00 & 28.00 & 126.00 \\
\hline $\mathrm{Pb}$ & 2030.00 & 5.80 & 2035.80 \\
\hline $\mathrm{Se}$ & 14.00 & 0.40 & 14.40 \\
\hline $\mathrm{Zn}$ & 840.00 & 35.80 & 875.80 \\
\hline
\end{tabular}

Source: Lantzy and Mackenzie 1979, p. 511 
assessments of global atmospheric flows that do not consider natural enrichment underestimate the contribution from natural sources to the global cycling of trace metals (Galloway et al. 1982). Lantzy and Mackenzie (1979) agree that while there is a correlation between enrichment factors (atmospheric abundances) and anthropogenic emissions, the relationship is not necessarily one of cause and effect. They conclude that natural processes may be more important than anthropogenic activities in causing the increased enrichment factors.

\subsection{Natural Sources}

The major sources of natural emissions are windblown dust, volcanic emissions, bursting of seasalt bubbles, gas exchanges in the oceans, forest wildfires, emissions from soils and vegetation, and biogenic sources.

For some elements, natural emissions exceed those from manmade sources. Natural sources appear to dominate the atmospheric emissions of selenium, manganese, and chromium, but there is a lack of reliable information about the quantities and physical and chemical characteristics of these emissions. Either no measurements are available or measurements by different authors disagree. For example, some sources suggest that the amount of mercury released by volcanic eruptions is large compared with most other natural sources (Nriagu 1989a, p. 48), while others propose that volcanic emissions are negligible compared with other sources (Lindqvist and Rodhe 1985, p. 149).

As shown in Table 2.3, Nriagu (1989a) indicated that volcanic eruptions release $40 \%$ to $60 \%$ of the cadmium and mercury and between $20 \%$ and $40 \%$ of the arsenic, chromium, copper, and lead naturally emitted. Seasalt spray is responsible for less than $10 \%$ of the natural emissions for most of these metals. Soilderived dusts account for more than $60 \%$ of the chromium and manganese, between $20 \%$ and $30 \%$ of the copper and lead, and less than $10 \%$ of mercury and selenium released from natural sources.

Biogenic sources were responsible for more than $50 \%$ of naturally emitted selenium and mercury and between $30 \%$ and $50 \%$ of arsenic released from natural sources. Lantzy and Mackeisice (1979) also suggest that lowtemperature volatilization as a result of biological activity may have a significant role in the cycling of mercury, arsenic, and selenium.

Table 2.3. Sources of Natural Emissions of Heavy Metals (\%)

\begin{tabular}{|c|c|c|c|c|c|c|c|c|c|c|}
\hline Source & $\underline{A s}$ & Cd & $\mathrm{Cr}$ & $\underline{\mathrm{Cu}}$ & $\underline{\mathrm{Hg}}$ & $\underline{\mathrm{Mn}}$ & $\underline{\mathrm{Ni}}$ & $\underline{\mathrm{Pb}}$ & Se & $\mathrm{Zn}$ \\
\hline Windborne Dust & 21 & 15 & 62 & 28 & 2 & 70 & 38 & 32 & 2 & 42 \\
\hline Seasalt Spray & 14 & 4 & 0 & 13 & 1 & 0 & 4 & 11 & 5 & 1 \\
\hline Volcanoes & 31 & 57 & 35 & 33 & 40 & 13 & 48 & 27 & 9 & 21 \\
\hline Forest Fires & 2 & 8 & 0 & 14 & 1 & 7 & 8 & 16 & 3 & 17 \\
\hline Biogenic Sources & 32 & 17 & 3 & 12 & 56 & 9 & 2 & 14 & 81 & 18 \\
\hline Total Natural Emissions & 100 & 100 & 100 & 100 & 100 & 100 & 100 & 100 & 100 & 100 \\
\hline
\end{tabular}

Source: Nriagu 1989a. 


\subsection{Anthropogenic Sources}

Controlling the emissions of heavy metals effectively requires an understanding of the major anthropogenic sources. Coal combustion is a major source of mercury and selenium, causing approximately $50 \%$ of the anthropogenic emissions of these metals. Coal combustion is also responsible for between $25 \%$ and $40 \%$ of chromium, manganese, and nickel emissions, as well as significant amounts of other heavy metals. Oil combustion was found to be a major anthropogenic source of nickel (over 50\%). The nonferrnus metal industry contributed between $50 \%$ and $70 \%$ of the arsenic, cadmium, copper and zinc emissions (Table 2.4).

\subsubsection{Coal Combustion}

Coal combustion is a major source of heavy metal emissions. The amount of trace metals released from coal combustion depends on many factors. As we reach an understanding of the parameters that affect heavy metal emissions, strategies can be developed to curtail these emissions. When coal burns, two factors that influence the amount of trace metals emitted into the atmosphere are the concentration of the elements in the coal and the physico-chemical properties of the elements during combustion (Pacyna 1986b, p. 3).

High concentrations of trace metals in coal increase the emissions of these elements into the environment. While it is difficult to generalize about trace metal concentrations, lignite and sub-bituminous coals contain less trace metals than hituminous coals; however, because almost two times the amount of lignite is needed to produce an amount of energy equal to that of bituminous coal, the use of lignite actually increases emissions (Pacyna 1987, p. 71). Table 2.5 shows the different types of coals by region throughout the world.

In addition to concentrations varying between different types of coal, concentrations of trace metals in coal also vary widely from region to region and even within regions. Table 2.6 gives the concentrations of heavy metals in coals from different regions in the United States. Neme (1991, p. 62) estimated that in the United States, switching from coals

Table 2.4. Sources of Anthropogenic Emissions of Heavy Metals (\%)

\begin{tabular}{|c|c|c|c|c|c|c|c|c|c|c|}
\hline Source & $\underline{\text { As }}$ & Cd & $\underline{\mathrm{Cr}}$ & $\underline{\mathrm{Cu}}$ & $\underline{\mathrm{Hg}}$ & $\underline{\mathrm{Mn}}$ & $\underline{\mathrm{Ni}}$ & $\underline{\mathrm{Pb}}$ & $\underline{\text { Se }}$ & $\underline{\mathrm{Zn}_{\mathbf{n}}}$ \\
\hline Coal Combustion & 10 & 7 & 37 & 15 & 59 & 28 & 27 & 4 & 48 & 9 \\
\hline Oil Combustion & $\mathbf{0}$ & 2 & 5 & 6 & 0 & 4 & 53 & 1 & 13 & 2 \\
\hline Pyrometallurgical & 66 & 72 & 0 & 67 & 4 & 8 & 9 & 24 & 37 & 57 \\
\hline Secondary Nonferrous & 0 & 0 & 0 & 0 & 0 & 38 & 0 & 0 & 0 & 1 \\
\hline Steel and Iron Manufacturing & 7 & 2 & 51 & 4 & 0 & 0 & 7 & 4 & 0 & 16 \\
\hline Refuse Incineration & 2 & 12 & 3 & 6 & 33 & 22 & 1 & 1 & 2 & 5 \\
\hline Cement Production & 3 & 4 & 4 & 0 & 0 & 0 & 1 & 3 & 0 & 11 \\
\hline Miscellaneous & 12 & 2 & 0 & 3 & 5 & 0 & 3 & 63 & 0 & 6 \\
\hline Total Anthropogenic Emissions & 100 & 100 & 100 & 100 & 100 & 100 & 100 & 100 & 100 & 100 \\
\hline
\end{tabular}


Table 2.5. Estimated Recoverable Reserves of Coal Worldwide (million tons) ${ }^{(a)}$

\begin{tabular}{|c|c|c|c|}
\hline Region & $\begin{array}{l}\text { Anthracite and } \\
\text { Bituminous }(\mathrm{b})\end{array}$ & $\begin{array}{c}\text { Total Recoverable } \\
\text { Lignite } \\
\end{array}$ & $\begin{array}{c}\text { Recoverable } \\
\mathrm{Coal}^{(\mathrm{c})}\end{array}$ \\
\hline United States $^{(\mathrm{d})}$ & 232,395 & 35,464 & 267,859 \\
\hline OECD-Europe & 37,595 & 51,711 & 89,306 \\
\hline OECD-Pacific & 55,104 & 46,203 & 101,307 \\
\hline USSR/E.Europe & 192,572 & 173,876 & 366,448 \\
\hline China and Southeast Asia & 67,381 & 132,240 & 806,057 \\
\hline Mideast & 213 & 0 & 213 \\
\hline Africa & 69,309 & 0 & 69,309 \\
\hline Latin America & 17,064 & 135 & 17,199 \\
\hline South and East Asia & 69,070 & 4,859 & 73,929 \\
\hline TOTAL & $1,347,139$ & 444,488 & $1,791,627$ \\
\hline
\end{tabular}

(a) World Energy Council definition of "Proved Recoverable Reserves": the tonnage of proved amount in place that can be recovered (extracted from the earth in raw form) under present and expected local economic conditions with existing available technology.

(b) Recoverable anthracite and bituminous data for the World Energy Council include sub-bituminous.

(c) Sum of components may not equal total due to independent rounding.

(d) For the United States, "Recoverable Anthracite and Bituminous" category represents the total for bituminous and sub-bituminous; estimates of recoverable reserves of anthracite are not currently available.

Sources: EIA 1989, 1991; World Energy Conference 1989

Table 2.6. Trace Metal Concentrations in Raw Coal (mg/mmBtu) $)^{(\mathrm{a})}$

\begin{tabular}{|c|c|c|c|c|c|c|c|c|c|}
\hline Coal Region & $\mathrm{Cd}$ & As & $\underline{\mathrm{Be}}$ & $\mathrm{Cr}$ & $\mathrm{Cu}$ & $\mathrm{Mn}$ & $\mathrm{Ni}$ & $\mathrm{Pb}$ & $\mathrm{Hg}$ \\
\hline N. Appalachia & 4 & 1616 & 84 & 699 & 695 & 1,265 & 654 & 321 & 9.13 \\
\hline S. Appalachia & 3 & 738 & 98 & 515 & 648 & 711 & 505 & 272 & 5.54 \\
\hline Interior & 169 & 774 & 97 & 628 & 679 & 3,074 & 1078 & 1578 & 5.94 \\
\hline Gulf Coast & 43 & 771 & 174 & 1260 & 1662 & 11,227 & 981 & 1564 & 16.17 \\
\hline North Dakota & 11 & & & & & & & & 10.17 \\
\hline Powder River & 8 & 264 & 42 & 335 & 597 & 2,347 & 293 & 274 & 6.15 \\
\hline Rocky Mountain & 9 & 201 & 85 & 388 & 534 & 2,006 & 307 & 477 & 4.67 \\
\hline
\end{tabular}

(a) USGS presents trace element concentration data in parts per million for each region. This table adjusts for average Btu content, as reported by USGS, by presenting data in milligrams per million Btu.

Source: U.S. Geological Survey, National Coal Resource Database (1989) in Neme (1991, pp. 44 and 63) 
from the Interior and Gulf Coast regions to coal from the Powder River and Rocky Mountain regions could reduce average emissions of cadmium, arsenic, chromium, copper, manganese, nickel, mercury, and lead. Similarly, countries, such as those in central and eastern Europe, that primarily burn lignite could reduce heavy metal emissions by switching to bituminous coal.

Some trace elements tend to concentrate on small particles in fly ash while other metals assume the vapor form during combustion. A third group concentrates in bottom ash. Metals that concentrate on small particles in fly ash or assume the vapor form are more likely to be emitted into the atmosphere than metals that concentrate in bottom ash (see box below). The conditions of combustion, such as combustion temperatures, also influence heavy metal emissions (Pacyna 1987, p. 69). Power plants that operate under high temperatures have greater emissions of trace metals than plants that operate under lower temperatures. Wet bottom boilers have the highest emissions of all the coal-fired utility boilers because they operate above the ash-melting temperature (the temperature at which the volatile trace metals in the coal ash evaporate). Wall-fired and tangential boilers have lower emissions because they operate under lower temperatures (Pacyna 1989 , p. 16).

\section{Behavior of Heavy Metals During Combustion}

During coal combustion, different elements concentrate in different waste streams. How these trace metals concentrate determines whether they are emitted from the stack as well as the effectiveness of control technologies in preventing their release. Because certain trace metals concentrate in fly ash, coal combustion releases these metals in higher concentrations than are found in feed coal (Kaakinen et al. 1975, p. 862). This means that heavy metals released from combustion are more concentrated, and potentially more dangerous, than concentrations found naturally in coal.

An analysis of bottom ash, ash from electrostatic precipitators, and fly ash found that trace elements have different behavior patterns after combustion. Arsenic, cadmium, lead, and zinc concentrate in fly ash; chromium and nickel sometimes concentrate in fly ash; and a mercury and selenium exist in the flue gases primarily in the vapor phase (Hasanen et al. 1986, p. 45). More than $90 \%$ of mercury in coal is released as vapor (Pacyna 1987, p. 72). Trace metals emitted as vapor are more likely to pass through control equipment than are particulates. Mercury emissions, which are equally volatile at high and low temperatures, remain as vapor in the plume and pass through the control equipment in gas form (Pacyna 1989, p. 89). Similarly, controls are not as effective at removing selenium as other elements because it also exists in the vapor phase (Mosher and Duce 1987, p. 13289).

As a result of combustion some trace metals concentrate on the smallest particles emitted. This is significant because small particles are not only the most likely to pass through the control devices, but also are most likely to be transported the greatest distances. Therefore, coal combustion not only serves to concentrate some heavy metals in the fly ash, but also concentrates the heavy metals in the particles that are most likely to be emitted from the stack. Small particles are more dangerous to humans than larger particles because they are easily inhaled. The elements that increase in concentration with decreases in particle diameter are mercury, lead, cadmium, selenium, arsenic, nickel, chromium, and zinc. These elements increase in concentration as particle size decreases because they vaporize during combustion, then condense and concentrate on the surfaces of the small ash particles as the flue gas cools (Pacyna 1987, p. 72; Hasanen et al. 1986, p. 45). 


\subsubsection{Utility Emissions in the United States}

Coal consumption is expected to continue to increase in the future. If estimates are correct, heavy metal emissions from electric utilities in the United States will continue to grow as well. Estimates of annual heavy metal emissions from coal-fired plants in the United States were calculated by Saeger et al. (1991) of the Alliance Technologies Corporation and by the Center for Clean Air Policy.

Saeger et al. (1991) estimated trace metal emissions from U.S. utilities by applying emission factors presented in the EPA report, Toxic Air Pollutant Emission Factors - A Compilation for Selected Air Toxic Compounds and Sources, to the 1985 NAPAP Emissions Inventory (Version 2).

The Center for Clean Air Policy estimated trace metal emissions from U.S. utilities by applying emissions factors calculated by Radian Corporation (Brooks 1989) to a national toxic emissions database that the Center developed. Information for the database was obtained from EPA's National Utility Reference File (NURF), DOE 767 forms that utilities file annually, EIA's inventory of Power Plants 1987, EIA 1985-1987 data for NAPAP, and Cost and Quality of Fuels for Electric Utility Plants 1987 (DOE 1991).

A comparison of the emissions estimates developed by Saeger et al. and the Center for Clean Air Policy (Table 2.7) shows that although differences exist, the results are similar in magnitude. It is difficult to make anything other than an order of magnitude comparison because each study uses different base years and different inventories. Estimates from the Center for Clean Air Policy are probably more accurate because revised emission factors and a more extensive inventory were used.

\subsubsection{Utility Emissions in Europe}

Pacyna calculated emissions of arsenic, cadmium, mercury, zinc, and lead for major anthropogenic sources in Europe. Pacyna's results are presented in Table 2.8. Data from 633 conventional power plants were used to

Table 2.7. Utility Emissions of Selected Trace Metals in the United States (tons per year)

\begin{tabular}{lllllllll}
\multicolumn{1}{c}{ Reference } & Year & $\frac{\mathrm{As}}{\mathrm{Cd}}$ & $\frac{\mathrm{Cr}}{\mathrm{Cl}}$ & $\mathrm{Hg}$ & $\mathrm{Mn}$ & $\mathrm{Ni}$ \\
\cline { 1 - 4 } & 1985 & 574 & 113 & 3067 & 1380 & 99 & 5288 & 2743 \\
Center for Clean Air Policy & 1987 & 381 & 44 & 2474 & 1167 & 81 & 3470 & 2234
\end{tabular}

Sources: Saeger et al. 1991, p. 7; Neme 1991, p. 23

Table 2.8. Utility Emissions of Selected Trace Metals in Europe in 1982 (tons per year)

\begin{tabular}{|c|c|c|c|c|c|}
\hline Boiler Type & As & $\mathrm{Cd}$ & $\underline{\mathrm{Hg}}$ & $\mathrm{Pb}$ & $\mathrm{Zn}$ \\
\hline Coal & 237 & 81 & 122 & 844 & 1190 \\
\hline Oil & 91 & 43 & & 457 & 325 \\
\hline Total & 328 & 124 & 122 & 1301 & 1515 \\
\hline
\end{tabular}

Source: Pacyna 1989, p. 21 
determine production capacity and the type of fuel used by conventional plants. They calculated emission factors using information on the boiler type and the efficiency of the emission control equipment for given countries.

\subsubsection{Oil Combustion}

Except for its nickel emissions, oil combustion is a less significant source of heavy metal emissions than coal combustion. While there is a high variability of trace elements in oil, heavy metals are usually not present in residual and distillate oil in large quantities. Therefore, when oil is burned, the releases tend to be smaller. Oil combustion is, however, a major source of nickel emissions.

Since oil combustion does not produce bottom ash, $100 \%$ of the trace metals entering the boiler are assumed to be emitted in the flue gas. Oil fly ash has different characteristics than coal fly ash, and it is not known whether trace metals are enriched in the small particle fractions of oil ash the way they are in coal ash. Without this information, the ability of particulate control equipment to remove trace metals cannot be evaluated. As a result, most emissions factors for oil are reported for uncontrolled boilers.

\subsubsection{Other Anthropogenic Sources}

In addition to coal and oil combustion, the other major industrial sources of atmospheric heavy metal emissions are nonferrous metal production and the production and use of metallic commercial products. Other manufacturing processes, refuse incineration, and chlor-alkali waste ponds also contribute to emissions.
The production of nonferrous metals involves several steps that result in the release of heavy metals. The first step is mining. Underground and open-pit mining techniques both release trace metals because nonferrous metal ores contain cadmium and arsenic. Next, the ores are roasted in smelters. This high-temperature process separates volatile elements, such as arsenic, cadmium, and mercury, from the ores. These trace metals remain in the flue gas. Most of the metals in the flue dusts are recycled, but any that are not, are emitted to the atmosphere. Emissions are dependent on the efficiency of the control devices used.

Secondary nonferrous metal production proc esses, such as the melting of scrap, the oxidation of impurities in the scrap, and the refining of copper, also result in trace element emissions. The furnaces used in iron and steel manufacturing and the kilns in cement production also emit trace metals. Trace element emissions are also released from municipal incinerators and sewage sludge incineration.

Chlor-alkali plants are a source of mercury emissions that have an impact, at least on local levels. One study suggests that in addition to mercury losses that occur during production processes in active chlorine plants, atmospheric and aquatic emissions may also occur from ponded waste products at active or inactive plants (Lindberg and Turner 1977, p. 133). Since ponding is a common disposal practice for solid waste, and since mercury has a residence time of over 100 years in large waste deposits, the relative importance of emissions from waste ponds may continue to grow. 


\subsection{Environmental Transport and Behavior}

The primary vehicles of heavy metal transport are atmospheric transport and leaching. Heavy metal emissions to the air are likely to be carried long distances and deposited in distant terrestrial and aquatic environments. The leaching of trace metals usually involves shorter distances and depends on the solubility of the metals in water and the amount of water available as a transport medium.

After heavy metals are released into the environment, they interact with other chemicals, such as sulfur dioxide and nitrogen oxide. Both sulfur dioxide and nitrogen oxide have been linked to acid rain. The relationship between certain heavy metals and these substances influences the concentrations and bioavailability of these metals in aquatic ecosystems.

\subsection{Air Transport}

The behavior of elements during atmospheric transport depends on their physical-chemical properties; their particle size-distribution; and meteorological conditions, such as wind speed (Pacyna 1987, p. 81). The concentration of elements in the air seems also to vary with the seasons (Lindqvist and Rodhe 1985, p. 857).

Air emissions from utility and other types of boilers are usually released from tall stacks. Tall stacks permit air emissions to be transported long distances, which can result in significant air deposition in areas far from the source of these pollutants (Saeger et al. 1991). Additionally, the residence time of trace elements in the atmosphere is long enough to allow for long-range transport. For example, arsenic, cadmium, and lead reside in the atmosphere for approximately seven days (Pacyna 1987, p. 81).
Trace metals leave the atmosphere through wet deposition (rainfall) or dry deposition (sedimentation). The solubility of the metals in water determines whether they will be removed by wet deposition. Mercury is unusual because it can be re-vaporized after it has been deposited on land.

Atmospheric deposition is an important pathway by which trace metals enter the environment. For example, Lake Michigan receives approximately $50 \%$ of its toxic input from atmospheric deposition, an amount equal to the discharge of effluents directly into the lake by industry (Neme 1991, p. 17). Similarly, meteorological studies and geographical concentration patterns indicate that trace element emissions from the northern (former) Soviet Union are the main sources of the high concentrations of air pollutants in the Norwegian Arctic (Pacyna et al. 1985, p. 857).

The vapor form of mercury makes long-range transport and long residence times in the atmosphere possible. The residence time of mercury in the atmosphere usually ranges from 0.7 to 2 years. Other estimates based on oceanic measurements support this time frame (Lindberg 1987, p. 101). Because of its long residence time in the atmosphere, mercury is deposited in areas outside of those in which it is emitted. For example, other European countries probably contribute more to the current mercury deposition in Sweden than Swedish emissions do (Lindquist and Rodhe 1985, p. 154).

\subsection{Leaching and Other Trans- port Pathways}

In addition to stack emissions, there are other processes by which trace metals enter the environment as a result of coal combustion. 
Trace elements can also enter the environment as a rusult of coal pile run-off. Coal pile runoff is caused by rainfall that percolates through the coal storage piles. Acid leachate is produced, which holds the metals in solution and facilitates transport of these metals to surface water and groundwater.

Ash pond water discharge is another means by which heavy metals can enter the environment. Fly ash from electrostatic precipitators and bottom ash from furnaces can release metals into the water in which they are traveling from the precipitators or furnace to the settling pond. Ash pond effluents usually discharge into rivers. Surface water and groundwater could also be contaminated. Toxic metals can also be released as a result of other waste water discharges. Finally, ash disposal could potentially contaminate soils, surface water, and groundwater. Ash containing trace metals can be transported long distances via cerial plumes, water, and with solid waste, all of which could contaminate the food chain (Sabbioni et al. 1984, p. 143).

Beaver et al. (1987) determined that the single most important factor in preventing groundwater contamination from fly ash and/or flue gas desulfurization waste sites is to keep the wastes $d_{i} y$ and to dispose of them in dry settings. If no water is present, there is no transport medium to move the contaminants.

In a 1976-1979 study, Wangen and Dreesen $(1980$, p. 1-2) sought to identify which elements were mobilized in the scrubber system and ash disposal pond at the Four Corners Power Plant in northwestern New Mexico, a plant that uses a coal with an unusually high ash content of $20 \%$. They compared elements in the intake water with those in plant effluents. The elements most elevated in the effluent were the elements most highly extracted from precipitator ash by water. An important consideration is whether the trace elements in the ash are soluble in the acidic environment of the venturi scrubber or in the alkaline conditions in the ash disposal system. Trace elements that are mobilized in alkaline environments are mobilized in coal ash ponds. Undesirable ecological impacts could result from coal ash or scrubber sludge disposal.

Simsiman et al. (1987) point out that the ponding of fly ash permits the fly ash to contact water. This contact could lead to enhanced leaching of trace metals and contamination of the groundwater. A barrier to leaching is that the elements are usually found in the ash pond as particulates and their mobilization is limited by adsorption, precipitation, or other reactions that decrease their concentrations in the ash ponds.

\subsection{Relationship with Acid Rain}

A relationship exists between heavy metals and acid rain. First, both are caused by coal combustion. The combustion of coal not only releases heavy metals into the atmosphere, but it also releases sulfur dioxide and nitrogen oxide, the precursors to acid rain. Second, a statistical relationship exists between acidity in lakes and the concentration of metals in those lakes. Third, acid rain may increase fish uptake of metals and exacerbate the effects of metals on soils. The relationship between acidity and metal concentrations in lakes and fish is not well understood.

Several theories may explain why lakes that become acidic also have greater concentrations of certain heavy metals. These theories examine the processes by which lakes receive heavy metals, deposition and leaching. Lindqvist and Schroder (1989, p. 307) found that acidity in rain increased the atmospheric deposition of mercury by oxidizing elemental mercury in cloud water. Therefore, mercury deposition may not depend only on mercury emissions, but also on emissions of sulphur dioxide and nitrogen oxides. Lindqvist and 
Schroder found that elevated acidification increases the leaching of mercury from certain layers of the soil as the soil is dissolved in runoff water. Richman et al. (1988) also theorize that acidic conditions could mobilize sediment-bound mercury in the watershed and that it could enter the lake as runoff.

Acidity in lakes also increases the concentration of certain heavy metals in fish. Fish in low-pH lakes in Scandinavia, Canada, and the United States were shown to have elevated mercury concentrations, even in waters lacking direct anthropogenic sources of mercury (Suns et al. 1980; Sloan and Schofield 1983; Bjorklund et al. 1984; and Heiskary and Helwig 1986 all in Wiener 1988). Sprenger et al. (1988, p. $375-388$ ) analyzed trace element concentrations in yellow perch in six acidic lakes in northern New Jersey and found that concentrations of mercury and lead were highest in the most acid lakes, while cadmium showed fairly low accumulation.
There are several hypotheses as to why acidity is linked to increased concentrations of mercury. One reason could be that the uptake of mercury across the gills of fish is enhanced in waters with low $\mathrm{pH}$ or low calcium. Another possibility concerns the chemical form of the mercury. Methyl mercury is one of the most poisonous forms of mercury and is the form most easily bioaccumulated. Methyl mercury production is likely to increase in lakes under acid conditions. This increased production of meth; mercury could be responsible for the increased accumulation in fish (Wiener 1988; Richman et al. 1988).

Unlike mercury, cadmium and lead do not biomagnify in the aquatic food chain. Concentrations of these elements do not increase as the fish's body size increases. Lead is similar to mercury in that increased uptake occurs under acidic conditions. Cadmium concentrations in fish and other aquatic organisms decreased under acidic conditions. 


\subsection{Environmental and Health Effects of Heavy Metals}

Little is known about the impact of the longrange transport of trace metals and the effects of small doses of trace metals on humans and ecosystems. EPA assessments of potential risk, especially those focusing on air quality problems, have tended to concentrate on cancer risks to humans who inhale the air in the immediate area surrounding polluting facilities.

Carcinogens pose a threat in any quantity because they have no threshold. EPA has hoped that the focus on cancer risk would also eliminate other risks (which do have a threshold). Also, trace element uptake is more efficient through inhalation than through digestion (Austin and Millward 1984, p. 1909). EPA's focus on human carcinogenesis, however, neglects risks to humans and animals through bioaccumulation of metals in the food chain. EPA has not studied the impact of trace metals on animals and ecosystems, exposure through accumulation in the food chain, and the impact of long-range transport of heavy metals (Neme 1991).

Heavy metal pollution has become a concern to some scientists because trace metal emissions cause increased trace metal concentrations in air, toxicity in rainfall, trace metal deposition in fragile ecosystems far from industrial activity, and effects on flora and fauna (Nriagu 1989b, p. 4). Concentrations of some trace metals in fish and mammals exceed the health standards for people who eat those animals. Heavy metals pose a serious threat to aquatic ecosystems. Some metals have a tendency to bioaccumulate or biomagnify as they move through the aquatic food chain. Humans may not be the species most sensitive to trace metal accumulation; fish-eating mammals and birds may be at higher risk because fish makes up a greater portion of their diet. Heavy metals also have an adverse affect on soils. Although the impact of toxics on terrestrial ecosystems has not been studied in depth, the risks posed by trace metals to plants are likely to impact the animals eating the plants more than the plants themselves (Neme 1991).

Members of a workshop sponsored by the Center for Clean Air Policy evaluated metals to determine which were of greatest concern. The evaluation criteria were 1) evidence of adverse ecological effects; 2) human health effects resulting from intake through the food chain; 3) regional effects, i.e., not effects from a point source; and 4) ecological effects related to the atmosphere. The workshop did not address the effects to ecosystems of long-term heavy metal accumulation at current emission levels.

The members of the workshop concluded that mercury and cadmium pose a regional ecological threat. Not only have numerous health advisories been issued on eating fish caught in mercury-contaminated lakes, but there is evidence of adverse effects on loons, mink, and otter, all of which eat fish. Health advisories against eating moose, deer, and bear kidneys and liver have also been put into effect because of unhealthy levels of cadmium. The regional effects of some metals are uncertain, but the workshop found no evidence that air emissions of other metals are of concern today.

The effects of long-term human exposure to trace elements have not been fully explored. One author concluded that the increase in heavy metal pollution as a result of coal combustion is not likely to cause toxicological effects through the food chain, but that 
inhalation may have an impact. This impact occurs because small particles gain access to the alveolar regions of the lung and then enter the bloodstream (Sabbioni et al. 1983, p. 141, 147).

Mercury is emitted primarily in vapor form. This has serious implications because crop plants are likely to absorb and retain mercury through leaf uptake of mercury vapor. Also, inhaled mercury vapor diffuses into the blood cells and various tissues more effectively than does the particle form.
While all of the potential health risks posed by trace metals are not known, the hazards posed by these elements (at least in large quantities) have been documented. Certain forms of chromium, nickel, beryllium, arsenic, and cadmium are carcinogenic to animals and humans. Arsenic is a cocarcinogen that interferes with repair mechanisms. Selenium, an essential element, is not a carcinogen and is even considered to be an anti-carcinogen; however, in large quantities it is toxic to humans (Merian 1984, p. 25). 


\subsection{Control Strategies}

Heavy metal emissions can be reduced in several ways. Although existing control technologies were designed to remove particulates and sulfur dioxide, these technologies also remove heavy metals from flue gas. New technologies being developed can remove mercury from stack emissions. In addition to technologies, other options such as energy efficiency improvements, ccal cleaning, and fuel switching also are available to reduce heavy metal emissions.

\subsection{Existing Technologies}

The control technologies used by coal-fired power plants are electrostatic precipitators (ESP), baghouses, or scrubbers. ESP is the most commonly used control device. Wet-type ESPs are more efficient than conventional precipitators, with an efficiency of more than 99\%. Wet scrubbers are more efficient in removing arsenic, cadmium, manganese, nickel, lead, and zinc from flue gas than are ESPs, although ESPs are better at removing selenium. One drawback of wet scrubbers is their very high operating and maintenance costs.

Because most trace metals are emitted as particulates, retrofitting baghouses to existing coalfired power plants would reduce heavy metal emissions. Baghouses are more efficient at removing heavy metals than ESPs because baghouses are bettcr equipped to remove small particles. Thus, a baghouse can remove more trace metals from the flue gas than an ESP that has the same overall efficiency (Lane and Khosla 1983, in Neme 1991, p. 59). Unfortunately, these fabric filters wear down easily because of the high temperature and chemical properties of the flue gas.

\subsection{Developing Technologies}

Flue gas desulfurization is a nontraditional method of controlling emissions. This method retains trace elements in the particulate and in the vapor phases. Because they operate under lower temperatures, nonconventional ccmbustion methods, such as fluidized bed combustion, could lower emissions by reducing volatilization (Pacyna 1989, p. 15-22; Pacyna 1986, p. 4).

Most mercury leaves power plants in the vapor form. Most of the existing control technologies are not effective in preventing this vapor from escaping; however, several technologies are being developed to control mercury emissions. As Table 5.1 indicates, these emerging technologies remove mercury more efficiently than do existing controls. In the first technology, activated carbon is injected into flue gas to increase the efficiency of existing controls. In the second emissions-control technology, sodium hypochlorite is injected into a wet scrubber to make mercury water-soluble. The mercury is then removed from the scrubber waste water. A third technology being developed is the lignite coke technology; lignite coke adsorbs nearly $100 \%$ of mercury and other heavy metals from flue gas.

\subsection{Energy Efficiency}

Since it is possible that mercury removed by particulate controls or scrubbers could later volatize out of their waste products (Chow et al. 1990, in Neme 1991, p. 49), control strategies that would prevent mercury from undergoing combustion in the first place may be most effective in curtailing its emissior 
Table 5.1. Efficiency of Control Technologies at Removing Mercury

\begin{tabular}{lr}
\multicolumn{1}{c}{ Control Technology } & Efficiency \\
\hline Existing Technologies & \\
Hot-side ESP & $0 \%$ \\
Cold-side ESP & $35 \%$ \\
Baghouse & $40 \%$ \\
Scrubber & $35 \%$ \\
& \\
Developing Technologies & \\
Activated Carbon with Scrubber and ESP & $80 \%$ \\
Activated Carbon with Scrubber and Baghouse & $>90 \%$ \\
Sodium Hypochlorite with Scrubber & $>95 \%$ \\
Lignite Coke & $>95 \%$
\end{tabular}

Source: Neme 1991, p. 40

Energy efficiency could be the most effective method of reducing mercury and other emissions if the efficiency improvements displace electricity that is produced from coal-fired power plants (Neme 1991, p. 38-42). Energy efficiency would reduce the amount of trace metals, carbon dioxide, sulfur dioxide, and nitrogen oxides emitted. Energy efficiency is also highly cost-effective. The problem with this strategy is that its implementation depends on government involvement, utility investments, and changes in consumer behavior at levels that are not anticipated in the near future. Because coal use is expected to increase significantly in the next 20 years in the United States, energy efficiency improvements would only serve to keep emissions constant at today's levels if no other controls are implemented.

\subsection{Coal Cleaning}

The efficiency of coal cleaning depends on how easily the metals are removed from the coal and on the region of the country in which the coal is produced.
Some metals are more easily removed from coal than others. For example, arsenic, manganese, and lead are most easily removed. Also, heavy metals are more easily removed from enstern or midwestern coal than from western coal.

\subsection{Fuel Switching}

Fuel-switching could also be a means of reducing mercury and other trace metal emissions. Switching to nuclear or renewable energy would reduce heavy metal emissions by $100 \%$. Switching to natural gas would also reduce emissions, but because there are no available data on concentrations of trace metals in natural gas, these savings cannot be quantified. Oil-fired boilers do not require fly ash removal equipment. With the exception of nickel, emissions from oil-fired boilers are so low that they are comparable to those from a coal-fired unit with 99\% efficiency (Pacyna 1987, p. 73). Switching to different types of coal can significantly reduce heavy metal emissions, also. 


\subsection{Ongoing Activities}

Several organizations are conducting research to understand the process and impact of heavy metal releases better. These groups are trying to coordinate their efforts.

The U.S. Department of Energy's Pittsburgh Energy Center is doing field tests to determine the contents of emissions from utility stacks. Between 8 and 16 coal utilities will be studied to analyze emissions and evaluate the performance of control technologies.

In another mercury study, the National Institute of Environmental Health Sciences is trying to determine the human threshold for mercury.

The Environmental Protection Agency (EPA) and the Electric Power Research Institute (EPRI) each have several studies under way.

\subsection{EPA Activities}

EPA is carrying out several emissions studies. The amendments to the Clean Air Act require EPA to perform a 3-year study of the possible health effects from utility emissions of air toxics. The act also requires a special 4-year study in which emissions, health and environmental risks, and control technologies for mercury will be examined. EPA is also conducting a Great Waters study to evaluate the deposition of pollutants on the Great Lakes, Chesapeake Bay, and coastal waters.

\subsubsection{Utility Study}

EPA's utility study will focus on examining direct exposure to air toxic emissions. Health effects that occur within a 50-kilometer radius of a plant will be studied. Field tests to determine exactly what is being emitted from utility stacks will be conducted. EPA will also do a risk analysis.

This study will focus on human health because that is what the CAA requires. The study will not consider threats to ecosystems and animals. It has not been determined if long-range transport and indirect exposure (i.e., through the food chain) will be examined. EPA has committed to completing the utility study by September 1994.

\subsubsection{Mercury Study}

EPA's study of the long-range transport of mercury is still in the planning stages. Global effects will not be studied, but certainly transport across the United States and maybe across the U.S./Canadian border will be examined. Health risks will be assessed, but it has not been determined how that assessment will be done.

EPA has committed to completing the mercury study by September of 1994 also.

\subsubsection{Great Waters Study}

EPA's study of the atmospheric deposition to the Great Lakes and coastal waters will use a model and samples collected from the field. This study seeks to determine the loading of these pollutants from the air relative to the total loading. The Great Waters study will also look at the effects of direct and indirect exposure to these toxics and will determine the regulatory revisions necessary to prevent these effects. 


\subsection{EPRI Activities}

EPRI is developing models so that utilities can estimate their own emissions. Studies are also being conducted to better understand how errissions are transported and transformed in the environment, and the impacts on human health and the environment. This research is intended to complement the studies being conducted by EPA. EPRI is working with $E_{:}^{P} / A, D O E$, and utility representatives to co rdinate research.

\subsubsection{PICES Project}

The EPRI project, PICES (power plant integrated systems: chemical emissions study), will assess the source and fate of chemicals in the process streams of fossil piants. This project takes all of the different outputs, of which airborne emissions is just one, into account. A catabase has been established that includes descriptions and concentrations of chemicals in power plant processes, as well as applicable regulations and health and environmental information. A power plant chemical assessment model will be made available to utilities so they can track their pathways and predict emissions and discharges from a set of chemical inputs and generation configurations.

EPRI aiso started a tield monitoring project in May 1990 to measure a variety of substances in the process and discharge streams of several representative power plants.
The data will be used to fill gaps in the PICES database and to validate the PICES model. The PICES project is also developing control technology guidelines so utilities can determine which technologies are appropriate in the event that additional controls are needed. A literature review is also being conducted to find information on emerging control technologies.

\subsubsection{Human Health Risk Models}

Several computer models are being developed by the Environmental Risk Analysis Program at EPRI to determine the risks that air toxics emissions pose to human health. The Airborne Emissions Risk Assessment Model (AERAM) represents individual sources. The AirTox model, an extension of AERAM, allows for multiple decisions and gives information on a range of outcomes. A third model, Risk PICES, is a multimedia model that will link existing models and allow for multiple chemical evaluations.

\subsubsection{Temperate Lakes Study}

Finally, EPRI is conducting a study on mercury in temperate lakes. The purpose of this study is to quantify sources of mercury and the processes that influence mercury accumulation. A model of mercury behavior in aquatic ecosyrtems has been developed. A field study to sather air data to identify the forms of mercury in the atmosphere is also going to be conducted. 


\subsection{Areas Where Future Research Is Needed}

Future research is needed to fill the gaps in our knowledge of trace metals. More data are needed on the sources of trace metals, the quantities of trace metal emissions, the environmental behavior and transport of trace metals, and the health and ecological effects of trace metals. Currently, our knowledge in these areas is limited, and existing data contain a high degree of uncertainty.

\subsection{Sources of Emissions}

All the sources of heavy metal emissions may not have been identified at this time. For example, a study of a non-operating chloralkali plant in the United States revealed that stored waste deposits were emitting mercury vapor to the atmosphere. This finding indicates that losses from defunct plants could approach that of active plants (Lindberg and Turner 1977, p. 136). Power plants, metal works, and other sources of trace metal emissions should be investigated to determine releases that may be occurring from residual waste deposits even after these facilities have ceased operations.

More research is needed to determine natural source strengths, such as wind-blown dust, erosion, and forest fires (Pacyna 1987, p. 84). The sea-to-atmosphere flux needs to be studied in more depth. The sea could be a large source of trace metal emissions near the equator where solubilities are less than in colder water in high latitudes. These metals may be emitted as vapor and transported to higher latitudes as part of the moving air mass. At higher latitudes, they condense onto existing particles and become enriched compared with lower latitudes (Lantzy and Mackenzie 1979, p. 523).

\subsection{Emissions Inventory}

Very few worldwide assessments of trace metal emissions have been conducted, and the few that have been done are crude estimates. A global emissions inventory on a country-bycountry or region-by-region basis is needed (Pacyna 1989, p. xii). Considering emissions sources on a country or regional basis is important because different areas have different sources. Also, differences in control technology, industrial activity, population density, and other factors that contribute to emissions vary by country and/or region.

\subsection{Behavior and Transport}

The behavior of certain metals once they leave the stack needs to be studied more closely. For example, an analysis of the lesser known reactions with mercury indicated that, under certain conditions, the half-life of mercury could be only a few minutes, as opposed to months or years (Lindberg 1987, p. 101). Heavy metals interact with other chemicals in the atmosphere, and these relationships need more exploration. For example, soot and ozone have been linked to the deposition of certain heavy metals from the atmosphere (Ebinghaus et al. 1992). Very little is known about the chemical form of certain heavy metals in the atmosphere (Merian 1984, p. 16, 24). The physical and chemical forms of trace metals released and their behavior in the atmosphere impacts their transport in the environment, their bioavailable fraction, and their toxic health and ecological effects (Sabbioni et al. 1984, p. 151). 
Although leaching of heavy metals from coal sludge is only a local concern, the disposal of coal residue could become a major problem in the future. With the Clean Air Act Amendments of 1990 , more scrubbers will be installed at power plants, increasing the amount of coal sludge produced each year. To determine how threatening these residues are, it will be necessary to study scrubber sludge to determine how trace elements behave in sludge and how to dispose of them safely.

The physico-chemical form of trace metals in ash pond effluents also needs to be studied. The flow rates of trace metals from coal pile drainage and release to the air, soil, and other endpoints need to be determined. The leaching and sorptive behavior of trace elements from ash and solid waste disposal needs to be studied because this behavior governs the rate of environmental transport, the bioavailability, and the ultimate health effects posed by these elements (Sabbioni et al. 1984, p. 151). In fact, the chemical form in which elements are taken up and react with critical cells has not been fully studied. The valence and speciation of elements determine their behavior in living organisms (Merian 1984, p. 12).

\subsection{Impacts of Trace Metal Emissions}

To appreciate the impact that heavy metal releases from coal-fired power plants and other sources will have over time, a global model that can project into the future needs to be applied to this problem. This model should be global in scale and should consider differences in equipment, controls, concentrations in coal, and other economic and demographic factors on a regional basis. The model should consider all potential waste streams and exposure pathways. As different control technologies take hold, heavy metals may pose less of a threat to air quality and become a liquid or solid waste issue.

\subsection{Control Strategies}

To reduce the risks posed by heavy metal pollution, control strategies need to be developed. These strategies will probably include a mix of hardware and policy options. Innovative technologies will need to be further explored and developed. More research is needed to determine what options are most $s$ i itable. 


\subsection{References}

Austin, L. S., and G. E. Millward. 1984. "Modelling Temporal Variations in the Global Tropospheric Arsenic Burden." Atmospheric Environment 18(9):1909-1919.

Beaver, F. W., G. H. Groenewold, O. E. Manz, and D. J. Hassett. 1987. The Effects of Fly Ash and Flue-Gas Desulfurization Wastes on Groundwater Quality in a Reclaimed Lignite Strip Mine Disposal Site. Final Report. DOE/FC/10120-2550, North Dakota Mining and Mineral Resources Research Institute, Grand Forks, North Dakota.

Brooks, G. 1989. Estimating Air Toxics Emissions from Coal and Oil Combustion Sources. PB-89-194229, National Technical Information Service, Springfield, Virginia.

Chilvers, D. C., and P. J. Peterson. 1987. "Global Cycling of Arsenic." Chapter 17 in Lead, Mercury, Cadmium and Arsenic in the Environment, eds. T. C. Hutchinson and K. M. Meema, pp.89-106. John Wiley \& Sons Ltd, Great Britain.

Ebinghaus, R., H. H. Kock, R. D. Wilken, M. Orren, and S. G. Jennings. 1992.

"Simultaneous Measurements of Mercury in Air and Precipitation, Ozone and Aerosol Black Carbon." Presented at the International Conference on Mercury as a Global Pollutant, Monterey, California. Electric Power Research Institute, Palo Alto, California.

Elias, R. W. 1989. "A Tiered-Profile Approach to a Global Trace Metal Emission Inventory." Chapter 4 in Control and Fate of Atmospheric Trace Metals, eds. J. M. Pacyna and B. Ottar, pp. 47-55. Kluwer Academic Publishers, The Netherlands.
Energy Information Administration (EIA). October 1989. Estimation of U.S. Coal Reserves by Coal Type. DOE/EIA-0529, U.S. Department of Energy, Washington, D.C.

Energy Information Administration (EIA). February 1991. International Energy Annual. DOE/EIA-0219(89), U.S. Department of Energy, Washington, D.C.

Galloway, J. N., J. D. Thornton, S. A. Norton, H. L. Volchok, and R. N. McLean. 1982. "Trace Metals in Atmospheric Deposition: A Review and Assessment." Atmospheric Environment 16(7):1677-1700.

Hasanen, E., V. Pohjola, M. Hahkalo, R. Zilliacus, and K. Wickstrom. 1986.

"Emissions from Power Plants Fueled by Peat, Coal, Natural Gas and Oil." The Science of the Total Environment 54:29-51.

Jaworski, Z., M. Bysiek, and L. Kownacka. 1981. "Flow of Metals into the Global Atmosphere." Geochimica et Cosmochimica Acta 45:2185-2199.

Kaakinen, J. W., R. M. Jorden, M. H. Lawasani, and R. E. West. 1975. "Trace Element Behavior in Coal-Fired Power Plants." Environmental Science and Technology 9(9):862-869.

Lantzy, R. J., and F. T. Mackenzie. 1979. "Atmospheric Trace Metals: Global Cycles and Assessment of Man's Impact." Geochimica et Cosmochimica Acta 43:511-525. 
Lindberg S. E. 1987. "Emission and Deposition of Atmospheric Mercury Vapor." Chapter 8 in Lead, Mercury, Cadmium and Arsenic in the Environment, eds. T. C. Hutchinson and K. M. Meema, pp.89-106. John Wiley \& Sons Ltd, Great Britain.

Lindberg, S. E., and R. R. Turner. 1977. "Mercury Emissions from Chlorine-Production Solid Waste Deposits." Nature 268(5616):133136.

Lindqvist, O., and H. Rodhe. 1985. "Atmospheric Mercury - A Review." Tellus 37b(3):136-159.

Lindqvist, O., and W. H. Schroeder. 1989. "Cycling of Mercury in the Environment with Emphasis on the Importance of the Element in Acid Rain Studies." Chapter 13 in Control and Fate of Atmospheric Trace Metals, eds. J. M. Pacyna and B. Ottar, pp. 15-31. Kluwer Academic Publishers, The Netherlands.

Mackenzie, F. T., and R. Wollast. 1977. "Sedimentary Cycling Models of Global Processes." Chapter 19 in The Sea, ed. E. Goldberg, pp. 739-785.

Merian, E. 1984. "Introduction on Environmental Chemistry and Global Cycles of Chromium, Nickel, Cobalt, Beryllium, Arsenic, Cadmium and Selenium, and their Derivatives." Toxicological and Environmental Chemistry 8:9-38.

Mosher, B. W., and R. A. Duce. 1987. "A Global Atmospheric Selenium Budget." Journal of Geophysical Research 92(D11):13289-13298.

Neme, C. 1991. Electric Utilities and LongRange Transport of Mercury and Other Toxic Air Pollutants. The Center for Clean Air Policy, Washington D.C.
Nriagu, J. O. 1989a. "A Global Assessment of Natural Sources of Atmospheric Trace Metals." Nature 338:47-49.

Nriagu, J. O. 1989b. "Natural Versus Anthropogenic Emissions of Trace Metals to the Atmosphere." Chapter 1 in Control and Fate of Atmospheric Trace Metals, eds. J. M. Pacyna and B. Ottar, pp. 3-13. Kluwer Academic Publishers, The Netherlands.

Nriagu, J. O. 1990. "Global Metal Pollution: Poisoning the Biosphere?" Environment 32(7)7-33.

Nriagu, J. O., and J. Pacyna. 1988. "Quantitative Assessment of Worldwide Contamination of Air Water and Soils by Trace Metals." Nature 333:143-139.

Pacyna, J. M. 1986. "Emission Factors of Atmospheric Elements." Toxic Metals in the Atmosphere, eds. J. O. Nriagu and C. I. Davidson, pp. 1-32. John Wiley \& Sons, New York.

Pacyna, J. M. 1987. "Atmospheric Emissions of Arsenic, Cadmium, Lead and Mercury from High Temperature Processes in Power Generation and Industry." Chapter 7 in Lead, Mercury, Cadmium and Arsenic in the Environment, eds. T. C. Hutchinson and K. M. Meema, pp.89-106. John Wiley \& Sons Ltd, Great Britain.

Pacyna, J. M. 1989. "Technological Parameters Affecting Atmospheric Emissions of Trace Elements from Major Anthropogenic Sources." Chapter 2 in Control and Fate of Atmospheric Trace Metals, eds. J. M. Pacyna and B. Ottar, pp. 15-31. Kluwer Academic Publishers, The Netherlands. 
Pacyna, J. M., B. Ottar, U. Tomza, and W. Maenhaut. 1985. "Long Range Transport to Trace Elements To NY, Alesund, Spitsbergen." Atmospheric Environment 19(6):857-865.

Richman, L. A., C. D. Wren, and P. M. Strokes. 1988. "Facts and Fallacies Concerning Mercury Uptake By Fish in Acid Stressed Lakes." Water, Air and Soil Pollution 33:465-473.

Ross H. B. 1985. "An Atmospheric Selenium Budget for the Region $30 \mathrm{deg} \mathrm{N}$ to $90 \mathrm{deg} \mathrm{N}$." Tellus 37b(2):78-90.

Sabbioni, E., L. Goetz, and G. Bignoli. 1984. "Health and Environmental Implications of Trace Metals Released from Coal-Fired Power Plants: An Assessment Study of the Situation in the European Community." The Science of the Total Environment 40:141-154.

Sabbioni, E., L. Goetz, A. Springer, and R. Pietra. 1983. "Trace Metals from CoalFired Power Plants: Derivation of an Average Data Base for Assessment Studies of the Situation in the European Communities." The Science of the Total Environment 29:213-227.

Saeger, M., C. R. Newman, and T. Young. 1991. Emissions and Control of Toxics from Fuel Combustion Sources. Draft Report. Alliance Technologies Corporation, Chapel Hill, North Carolina.

Simsiman, G. V., G. Chesters, and A. W. Andren. 1987. "Effect of Ash Disposal Ponds on Groundwater Quality at a Coal-Fired Power Plant." Water Resources 21(4):417-426.
Sprenger, M. D., A. W. McIntosh, and S. Hoenig. 1988. "Concentrations of Trace Elements in Yellow Perch (Perca flavescens) from Six Acidic Lakes." Water, Air, and Soil Pollution 37:375-388.

U.S. Department of Energy (DOE). 1991. "Cost and Quality of Fuels for Electric Utility Plants 1990." DOE Order EIA-0191 (90), Washington D.C.

Wangen, L. E., and D. R. Dreesen. 1980. Environmental Assessment of Trace Elements from Coal Combustion in the Semi-Arid West. Progress Summary Report for FY 1976-1979. LA-8660-MS, Los Alamos National Laboratory, Los Alamos, New Mexico.

Walsh, P. R., R. A. Duce and J. L. Fasching. 1979. "Considerations of the Enrichment, Sources, and Flux of Arsenic in the Troposphere." Journal of Geophysical Research 84(C4):1719-1726.

Wiener, J. G. 1988. "Metal Contamination of Fish in Low-pH Lakes and Potential Implications for Piscivorous Wildlife." Presented at the 52nd North American Wildlife \& Natural Resources Conference.

World Energy Conference. 1989. 1989 Survey of Energy Resources. United Kingdom in Kane et al. "Greenhouse Gas Emissions from Coal Combustion: A Global Perspective." Paper presented at the IEA/OECD Conference on Coal, the Environment and Development: Technologies to Reduce Greenhouse Gas Emissions.

Worldwatch Institute. 1986 "Action Needed to Stabilize Earth's Chemistry." Journal of the Air Follution Control Association 36(6): 1044-1045. 


\subsection{Bibliography}

Adriano D. C. 1986. Trace Elements in the Terrestrial Environment. Springer-Verlag, New York.

Ayres, R. U. 1989. "Industrial Metabolism." Chapter 2 in Technology and Environment, eds. J. H. Ausebel and H. E. Sladovich, pp. 23-49. National Academy Press, Washington, D.C.

Bergkvist, B., L. Folkeson, and D. Berggen. 1989. "Fluxes of $\mathrm{Cu}, \mathrm{Zn}, \mathrm{Pb}, \mathrm{Cd}, \mathrm{Cr}$, and $\mathrm{Ni}$ in Temperate Forest Ecosystems: a Literature Review." Water, Air and Soil Pollution 47:217-286.

Bolton, J. G. 1985. "Estimating the Chronic Health Risk from Coal-Fired Power Plant Toxic Emissions." Journal of Hazardous Materials 10:351-387.

Boutron, C. 1980. "Respective Influence of Global Pollution and Volcanic Eruptions on the Past Variations of the Trace Metals Content of Antarctic Snows Since 1880's." Journal of Geophysical Research 85(C12):7426-7432.

Boutron, C. 1982. "Atmospheric Trace Metals in the Snow Layers Deposited at the South Pole From 1928 to 1977." Atmospheric Environment 16(10):2451-2459.

Boutron, C., and S. Martin. 1980. "Sources of Twelve Trace Metals in Antarctic Snow as Determined by Principal Component Analysis." Journal of Geophysical Research 85(C10):5631-5638.

Boutron, C., and R. Delmas. 1980. "Historical Record of Global Atmospheric Pollution Revealed in Polar Ice Sheets." Ambio 9(5):210-215.
Buat-Menard, P., and R. A. Duce. 1987. "Metal Transfer Across the Air-Sea Interface: Myths and Mysteries." Chapter 11 in Lead, Mercury, Cadmium and Arsenic in the Environment, eds. T. C. Hutchinson, and $\mathbf{K}$. M. Meema, pp. 147-173. John Wiley \& Sons, Great Britain.

Bunzl, K., G. Rosner, and W. Schmidt. 1983. "Distribution of Lead, Cobalt and Nickel in the Soil Around a Coal-Fired Power Plant." Z. Pflanzenernachr. Bodenk. 146:705-713.

Cannon, H. L, and H. W. Lakin. 1976. Trace Metals in the Environment. PB-274 428, National Technical Information Service, Springfield, Virginia.

Carroll, G. J. 1988. Incinerator Ash Quality, Residue Characteristics, and Control of Heavy Metal Emissions. EPA /600/D-88/252, U.S. Environmental Protection Agency, Cincinnati, Ohio.

Cass, G. R., and G. J. McRea. 1986. "Emissions and Air Quality Relationships for Atmospheric Trace Metals." Chapter 5 in Toxic Metals in the Atmosphere, eds. J. 0. Nriagu, and C. I. Davidson, pp. 146-171. John Wiley \& Sons, New York.

Chester, R. E., J. Sharples, K. Murphy, and A. C. Saydam. 1983. "The Atmospheric Distribution of Lead over a Number of Marine Regions." Marine Chemistry 13:57-72.

Clarkson, T. W. 1989. "Mercury." Journal of the American College of Toxicology 8(7):12911295. 
Davison, R. L., D.F.S. Natusch, and J. R. Wallace. 1974. "Trace Elements in Fly Ash: Dependence of Concentration on Particle Size." Environmental Science and Technology 8(13):1107-1113.

Electric Power Research Institute (EPRI). 1991. "Mercury in the Environment." EPRI Journal, December 1991, pp. 4-8.

Electric Power Research Institute (EPRI). 1991. "New Focus on Air Toxics." EPRI Journal, March 1991, pp. 5-13.

Evans, D. H. 1987. "The Fish Gill: Site of Action and Model for Toxic Effects of Environmental Pollutants." Environmental Health Perspectives 71:47-58.

Fellows, R. J., P. Van Voris, J. Droppo, C. Ainsworth, R. Hicks, W. Walters, and C. Cushing. 1986. "Preliminary Environmental Assessment and Research Plan: Environmental Effects of Incineration of Municipal Sludge." Environmental Protection Agency, Corvallis, Oregon.

Heit, M. 1977. A Review of Current Information on Some Ecological and Health Related Aspects of the Release of Trace Metals into the Environment Associated with the Combustion of Coal. HASL-320, National Technical Information Service, Springfield, Virginia.

Hewitt, C. N. 1986. "Formation and Decomposition of Trialkyllead Compounds in the Atmosphere." Environmental Science and Technology 20(8):797-802.

Hunt, C. D., and D. L. Smith. 1982. "Remobilization of Metals from Polluted Marine Sediments." Canadian Journal of Fisheries and Aquatic Science 40(supp2):132-142.
Hutchinson, T. C. and K. M. Meema, eds. 1987. Lead, Mercury, Cadmium and Arsenic in the Environment. John Wiley \& Sons, Great Britain.

Hutton, M. 1987. "Human Health Concerns of Lead, Mercury, Cadmium and Arsenic." Chapter 6 in Lead, Mercury, Cadmium and Arsenic in the Environment, T. C. Hutchinson, and K. M. Meema, eds., pp. 53-67. John Wiley \& Sons, Great Britain.

Iyengar, G. V. 1984. "Reference Values for Elemental Concentrations in Some Human Samples of Clinical Interest: A Preliminary Investigation." The Science of the Total Environment 38:125-131.

Landy, M. P., and D. A. Peel. 1981. "Shortterm Fluctuations in Heavy Metal Concentrations in Antarctic Snow." Nature 291(5811):144-147.

Lester, J. N., ed. 1987. Heavy Metals in Wastewater and Sludge Treatment Processes; Volumes I and II, Treatment and Disposal. CRC Press Inc., Boca Raton, Florida.

Livett, E. A. 1988. "Geochemical Monitoring of Atmospheric Heavy Metal Pollution: Theory and Applications." Academic Press Inc., London.

Lynn, D. A. 1976. Air Pollution - Threat or Response. Addison-Wesley Publishing Company, Reading, Massachusetts.

Mcllvaine, R. W. 1992. "Global Air Pollution Control in 1992 and Its Relationship to the Solid Waste Industry. "Journal of the Air and Waste Management Society 42(3):254-258.

Mininni, G., and M. Santori. 1987. "Problems and Perspectives of Sludge Utilization in Agriculture." Agriculture, Ecosystems and Environment 18:291-311. 
Mitchell, B. A. 1980. "Acid Rain and Birds: How Much Proof is Needed?" American Birds 43(2):234-241.

Mosher, B. W., R. A. Duce, J. M. Prospero, and D. L. Savoie. 1987. "Atmospheric Selenium: Geographical Distribution and Ocean to Atmosphere Flux in the Pacific." Journal of Geophysical Research 92(D11):13,277-13,287.

Mumford, J. L., G. E. Hatch, R. E. Hall, M. A. Jackson, R. G. Merrill, Jr., and J. Lewtas. 1986. "Toxicity of Particles Emitted from Combustion of Waste Crankcase Oil: In Vitro and In Vivo Studies." Fundamental and Applied Toxicology 7:49-57.

Mumma, R. O., D. C. Raupach, J. P. Waldman, S.S.C Tong, M. L. Jacobs, J. G. Babish, J. H. Hotchkiss, P. C. Wszolek, W. H. Gutenman, C. A. Bache, and D. J. Lisk. 1984. "National Survey of Elements and Other Constituents in Municipal Sewage Sludges." Archives of Environmental Contamination and Toxicology 13:75-83.

Murray, F. 1984. "The Accumulation by Plants of Emissions from a Coal-Fired Power Plant." Atmospheric Environment 18(8):1705-1709.

Nriagu, J. O. and C. I. Davidson. 1986. Toxic Metals in the Atmosphere. John Wiley \& Sons, New York.

Nriagu, J. O. 1979. "Global Inventory of Natural and Anthropogenic Emissions of Trace Metals to the Atmosphere." Nature 279:409-411.

Nyangababo, J. T., and J. W. Hamya. 1986. "Separation and Preconcentration of Heavy Metals in Environmental Samples by Nicotinium Molybdophosphate Resin." Bulletin of Environmental Contamination Toxicology 36:924-928.
Pacyna, J. M. 1984. "Estimation of the Atmospheric Emissions of Trace Elements from Anthropogenic Sources in Europe." Atmospheric Environment 18(1):41-50.

Pacyna, J. M. 1986. "Atmospheric Trace Elements from Natural and Anthropogenic Sources." Toxic Metals in the Atmosphere. John Wiley \& Sons, New York.

Pacyna, J. M. 1986. "Source Receptor Relationships for Trace Elements in Northern Europe." Water, Air and Soil Pollution 30:825-835.

Pacyna, J. M., A. Semb, and J. E. Hanssen. 1984. "Emission and Long-Range Transport of Trace Elements in Europe." Tellus 36B(3):163-178.

Purves, D. 1985. Trace Element Contamination of the Environment. Elsevier Science Publishers B.V., The Netherlands.

Rippey, B., R. J. Murphy and S. W. Kyle. 1982. "Anthropogenicaly Derived Changes in the Sedimentary Flux of $\mathrm{Mg}, \mathrm{Cr}, \mathrm{Ni}, \mathrm{Cu}, \mathrm{Zn}$, $\mathrm{Hg}, \mathrm{Pb}$, and $\mathrm{P}$ in Lough Neagh, Northern Ireland." Environmental Science and Technology 16:23-30.

Saeger, M., C. R. Newman, and T. Young. 1991. "Comparative Estimates of Toxics Emissions from Fuel Combustion Sources." Paper presented at the AWMA Specialties Conference on Emissions Inventories, September 91, Duram, North Carolina.

Sanders, C. L. 1986. Toxicological Aspects of Energy Production. Macmillan Publishing Company, New York.

Schell, W. R. 1986. "Deposited Atmospheric Chemicals: A Mountaintop Peat Bog in Pennsylvania Provides a Record Dating to 1800." Environmental Science and Technology 20(9):847-853. 
Shendrikar, A. D. and D. S. Ensor. 1986. "Sampling and Measurement of Trace Element Emissions from Particulate Control Devices." Toxic Metals in the Atmosphere. John Wiley \& Sons, New York.

Steinnes, E. 1987. "Impact of Long-range Atmospheric Transport of Heavy Metals to the Terrestrial Environment in Norway. " Chapter 9 in Lead, Mercury, Cadmium and Arsenic in the Environment, eds. T. C. Hutchinson, and K. M. Meema. John Wiley \& Sons, Great Britain.

Ten Brink, H. M., A. J. Janssen, and J. Slanina. 1988. "Plume Wash-Out Near A Coal-Fired Power Plant: Measurements and Model Calculations." Atmospheric Environment 22(1):177-187.

Tyler, G. and M. Balsberg Pahlsson, G. Bengsston, and E. Baath. 1989. "HeavyMetal Ecology of Terrestrial Plants, Microorganisms and Invertebrates: A Review." Water, Air and Soil Pollution 47:189-215.

U.S. Department of Energy (DOE). 1991. "Inventory of Power Plants in the United States 1990." DOE Order EIA-0095 (90), Washington, D.C.

U.S. Department of Health and Human Services. 1991. Toxicological Profile for Nickel (Draft). U.S. Government Printing Office, Washington, D.C.

U.S. Department of Health and Human Services. 1991. Toxicological Profile for Beryllium (Draft). U.S. Government Printing Office, Washington, D.C.

U.S. Department of Health and Human Services. 1991. Toxicological Profile for Chromium (Draft). U.S. Government Printing Office, Washington, D.C.
U.S. Department of Health and Human Services. 1991. Toxicological Profile for Lead (Draft). U.S. Government Printing Office, Washington, D.C.

U.S. Environmental Protection Agency (EPA). 1987. Health Assessment Document for Beryllium. EPA Report No. EPA/600/8-84/026F, Research Triangle Park, North Carolina.

U.S. Environmental Protection Agency (EPA). 1984. Health Assessment Document for Chromium: Final Report. EPA Report No. EPA-600/8-83-014F, Washington, D.C.

Waldbott, G. L. 1978. Health Effects of Environmental Pollutants. The C. V. Mosby Company, St. Louis.

Webber, M. D., and D.G.M. Corneau, 1978. "Sludge Metal Solubilities in Soils." Soil Research Institute, Ottawa, Canada.

Williams, S. C., H. J. Simpson, C. R. Olsen, and R. F. Bopp. 1978. "Sources of Heavy Metals in Sediments of the Hudson River Estuary." Marine Chemistry 6:195-213.

Wilson, B. L., R. R. Schwartzer, and N. Etonyeaku. 1986. "The Evaluation of Heavy Metals (Chromium, Nickel, and Cobalt) in the Aqueous Sediment Surrounding a Coal Burning Generating Plant." Journal of Environmental Science and Health A21(8):791-808.

Yeats, P. A., and J. M. Bewers. 1983. "Potential Anthropogenic Influences on Trace Metal Distributions in the North Atlantic." Canadian Journal of Fisheries and Aquatic Science 40(supp2):124-131.

Zwozdziak, J. W. and A. B. Zwozdziak. 1985. "Evaluation of Atmospheric Trace Species in the Vicinity of a Copper Smelter and a Power Plant." International Journal of Environmental Studies 24:97-105. 

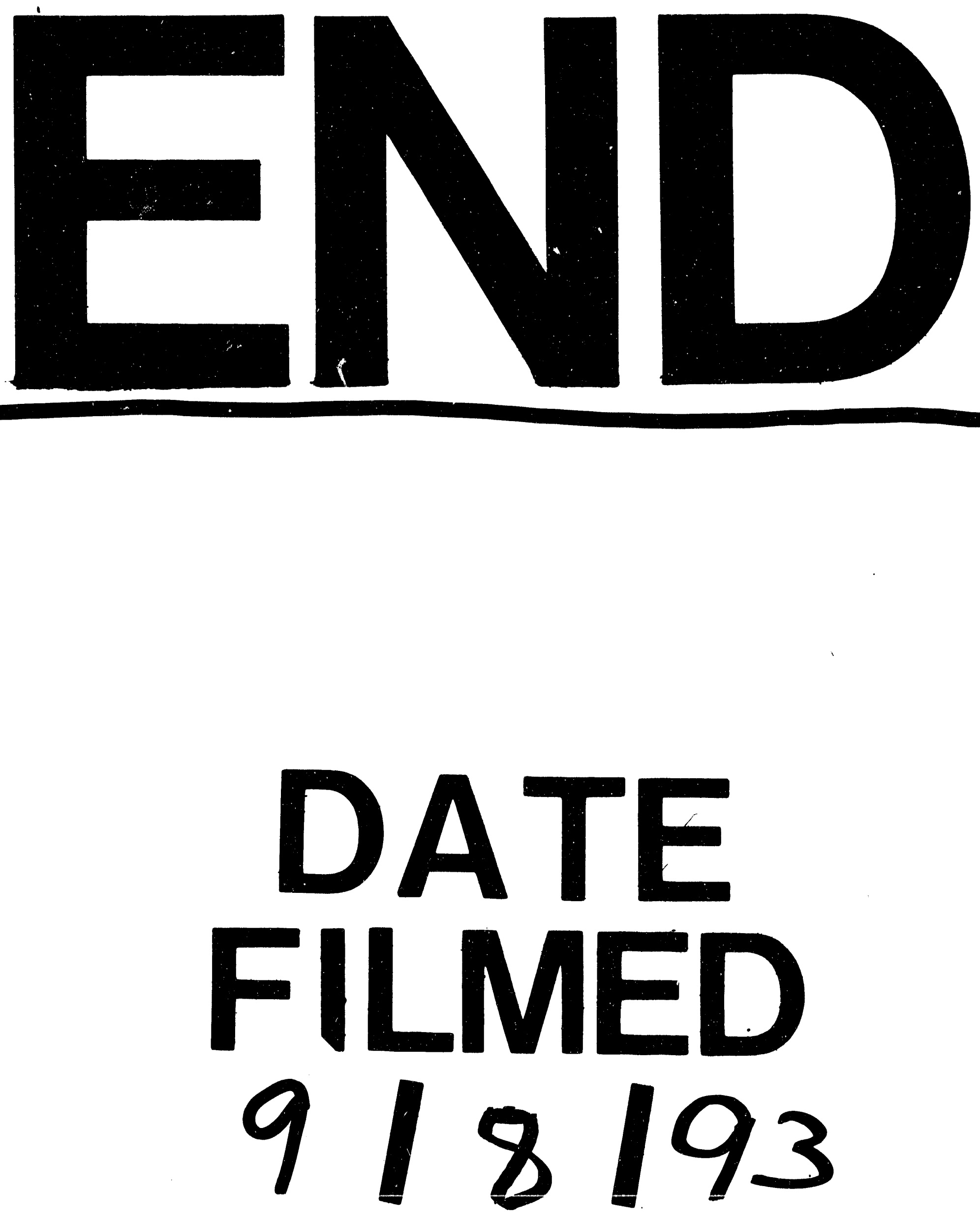
